\title{
The Evaluation of the Application of Fire Extinguisher Installation in the Plastic Sack Industry
}

\author{
Evaluasi Penerapan Pemasangan Alat Pemadam Api Ringan di Industri Karung \\ Plastik
}

\author{
Rosita Dwi Lufyana \\ Perhimpunan Sarjana dan Profesional Kesehatan Masyarakat Indonesia Jawa Timur (Persakmi \\ Jl. Tambang Boyo No.154, Pacar Kembang, Tambaksari, Surabaya, East Java 60132 Indonesia
}

\begin{abstract}
Introduction: Plastic sack industry is an industry that has medium (3) level of fire potential, caused by the material used in the production process is flammable and the industry itself uses electricity to generate heat. In this situation, a protection system is needed in the form of fire extinguisher. By seeing the fire potential in the plastic sack industry, this study aimed to evaluate the installation of fire extinguisher as an effort to prevent and control fire. Method: This study was an observational study through cross-sectional research design. The research samples were 45 fire extinguishers and the variables of the research were fire extinguisher installation process. Result: The classification of fire in the plastic sack industry was A, B, and C. The industry had 45 fire extinguishers spread through the whole production area and office area. It was found that there were three types of fire extinguisher with different capacity on every type, condition, label, height and the sign of installation that still did not comply to the regulation. Conclusion: Fire extinguisher installation in plastic sack industry does not follow the regulations such as procedures of installation and maintenance of fire extinguisher, team of fire prevention, color, the high of installation, condition and placement, label on tube, and marker of fire extinguisher, so it needs to take corrective actions to improve the performance of fire extinguisher when it is used.
\end{abstract}

Keywords: fire extinguisher, fire extinguisher installation, flammable material, plastic sack, protection system

\begin{abstract}
ABSTRAK
Pendahuluan: Industri Karung plastik merupakan industri yang memiliki potensi kebakaran sedang tingkat 3, hal ini dikarenakan bahan yang digunakan dalam proses produksi merupakan bahan yang mudah terbakar dan adanya sumber energi listrik untuk menghasilkan panas sehingga perlu adanya sistem proteksi untuk mencegah terjadinya kebakaran salah satunya adalah APAR. Melihat potensi kebakaran di Industri Karung Plastik tersebut, maka dilakukan penelitian ini yang bertujuan untuk mengevaluasi penerapan pemasangan alat pemadam api ringan sebagai upaya pencegahan dan penanggulangan terjadinya kebakaran. Metode: Penelitian ini merupakan penelitian observasional dengan rancangan penelitian cross-sectional. Sampel penelitian ini berupa 45 APAR Variabel penelitian ini adalah pemasangan APAR. Cara pengumpulan data diperoleh dengan checklist. Hasil: Klasifikasi kelas kebakaran yang ada di Industri Karung Plastik adalah A, B, dan C. Industri Karung Plastik Memiliki 45 buah APAR yang tersebar diseluruh wilayah produksi maupun kantor. Berdasarkan observasi yang dilakukan menunjukan bahwa terdapat 3 jenis APAR dengan kapasitas yang berbeda pada setiap jenisnya, kondisi, label, tinggi dan tanda pemasangan APAR ditemukan banyak yang belum sesuai dengan peraturan. Simpulan: Pemasangan APAR di Industri Karung Plastik masih terdapat hal yang belum sesuai dengan peraturan seperti prosedur pemasangan dan pemeliharaan APAR, tim pencegahan kebakaran, warna, tinggi pemasangan, kondisi dan penempatan, label pada tabung, dan tanda pemasangan APAR, sehingga perlu dilakukan perbaikan untuk meningkatkan kinerja APAR saat digunakan.Kata kunci: alat pemadam api ringan, bahan mudah terbakar, karung plastik, pemasangan alat pemadam api, sistem proteksi
\end{abstract}

Kata kunci: alat pemadam api ringan, bahan mudah terbakar, karung plastik, pemasangan alat pemadam api, sistem proteksi

\section{Corresponding Author:}

Rosita Dwi Lufyana

Email: rlufyana@gmail.com

Telephone: +6281285077494

\section{INTRODUCTION}

Plastic sack is one of many forms of packaging widely used in industrialization era that functions as a packaging of goods, whether it is raw or not. The main raw material used is polypropylene, while the 
supporting material is ink, which is used to beautify the sack. The ink is used as identifier which can be adjusted to what the customer needs. The material, whether it is the main material or the supporting material, has flammable characteristics. Moreover, the machine in the industry uses electricity as its main source of energy, which is susceptible to cause electrical shortages and leads to fire.

The use of technology and flammable materials on the production process must be accompanied with the increase of protection for the worker, as what has been stated on Law No. 1 of 1970 Concerning Work Safety article 3:1 concerning work safety stating that requirements for work safety is to prevent and reduce accidents on workplace and article 9:1 stating that every management is obliged to prevent accidents and eradicate fires. The same statement can also be found at the regulation made by the Indonesian Minister of Manpower KEP. 186/MEN/1999 concerning firefighting units in the workplace chapter 1 articles 2 that fire prevention units in the workplace, namely the management/ employer shall prevent, reduce and extinguish fires in the workplace and be carried out in accordance with applicable regulations.

Fire is a type of disaster that is often happened and can be classified as natural disasters or disasters caused by human activities. Fire can occur at any time because there are many triggers for fires (Tarwaka, 2012). According to Ramli (2010), fire can happen because of three factors that needed to create fire are met. The three factors are fuel, heat sources and oxygen $(\mathrm{O} 2)$. The fuel factor can be found in the form of gas, liquids or solid and mixed with the oxygen in the air. Heat can be the trigger of the fire with enough energy to light the mix of the fuel and oxygen. Without the presence of air or oxygen, the process of creating fire cannot happen.

National Fire Protection Association (2013) also said that fire is an oxidation process that involves three elements, which are flammable fuel, oxygen in the air and heat/energy source that can result in loss of possession, injury or even death. Along with the technology development, fire triangle theory also has been developed with the founding of the fourth element which is Chemical Chain Reaction. This theory is known as fire tetrahedron. The fourth element in combustion process is chemical chain reaction between the fuel and the oxidation. This fourth process can cause temperature to increase which will cause the oxygen to be absorbed in fire area and will increase combusting reaction in return (Tarwaka, 2012).
Fire disasters often happened in Indonesia, whether in neighborhood, forestry, or industry. Fire in industrial can cause many injuries and loss, like the one happened in 2004. This happened at PT. Petrowidada in Manyar, Gresik, East Java, which has costed the life of two workers. The same thing also happened at PT Lautan Otsuka Chemical in Cilegon, Banten, back in 2009. This caused five persons to be injured. Furthermore, there was also fire that happened in a textile industry located in Batujajar, Bandung, West Java which was PT. Politek reaching billions of rupiah loss. Few more examples when the fire happened to industries are in Surabaya which PT KICI reaching 20 billion rupiah of loss and CV. Matini Food, a snack industry, which also had the same problem caused by the production machine inside the factory. Jakarta is one of region in Indonesia that experienced lots of fire and according to a study based on the data in 2013, there were 7 fire disasters that caused millions of rupiahs of loss only from January until October 2013 (Firdani, Ekawati and Kurniawan, 2014).

Fire disaster also have negative effect on the workers who are affected by the event which can cause physical disabilities, trauma and losing their job, while for the company itself, the loss will be in the form of property damage, document damage and the cessation of production process. Moreover, fire can cause environmental damage and health problems caused by the smoke (Suma'mur, 2009).

Prevention and countermeasures of fire should be done to minimize the loss and damage caused by the fire. Prevention and countermeasures are efforts to be aware of the factors of fire and to take a step further from the fire becoming a reality (Tarwaka, 2012). Every workplace has fire potential that can happen anytime. Workplace can be categorized into fire classes made by the regulations of the Indonesian Minister of Manpower KEP. 186/MEN/1999 Concerning firefighting unit in workplace, and plastic sack industry is categorized as medium level (3), because the plastic sack industry is a workplace that has high number of fire potential and if fire indeed happened and release high temperature, the fire will spread quickly.

The high fire risk level in workplace requires the management to take precautions by providing fire protection facilities and infrastructures and prepares their worker to anticipate and to deal with the fire. According to Ramli (2010), fire protection system aims to detect and extinguish fire as quickly as possible with manual or automatic equipment. 
Fire protection system is divided into two, which are active fire protection system and passive protection system.

The first step to prevent fire in a company is to create an emergency response team and provide installation of fire extinguisher as an active fire protection that will be effective enough to extinguish fire right when it occurs. According to the regulation made by the Indoneisan Ministry of Manpower and Transmigration PER.04/MEN/1980 concerning requirements and maintenance of fire extinguisher, fire extinguisher is a light and easily carried by one person equipment to extinguish the fire when it occurs. Tarwaka (2012) stated that fire extinguisher is one of many active fire protection equipment that that can be used to extinguish and control fire and is an equipment mostly used in emergency situation.

Because of the importance of fire extinguishers in protecting fires, therefore the installation and maintenance of fire extinguishers need to be taken care of. According to Lestaluhu (2019), fire extinguisher installation which is compatible with company policy and according to the requirements from the Indonesian Ministry of Manpower and Transmigration PER.04/MEN/1980, is the main factor in maximizing the efforts of prevention at initial level fire so that when it is needed, fire extinguisher can be utilized.

According the Indonesian Ministry of Manpower and Transmigration PER. 04/MEN/1980, regarding the Requirements for the Installation and Maintenance of Light Fire Extinguishers, the correct fire extinguisher installation must pay attention to the location of the placement, namely in a location that is easily seen, easily reached and installed based on the potential fire hazard at work.

In addition to the materials and technology used, the plastic sacking industry only has an active fire protection system in the form of a fire extinguisher. There are several things in the plastic sack industry that are still not compatible with standards. Based on these problems, it is essential to research on the application of fire extinguisher installation in the Plastic Sack Industry. The purpose of this study was to evaluate the application of the installation and maintenance of fire extinguishers in the plastic sack industry as an effort to prevent and tackle fires based on the Indonesian Ministry of Manpower and Transmigration PER.04/MEN/1980 regarding the Requirements for the Installation and Maintenance of Fire Extinguishers.

\section{METHOD}

The data collection method used in this study was observational because there was no treatment on the variables studied. Based on the time of the study, it was cross-sectional. The data was collected based on the variables studied simultaneously at a certain time. Based on the analysis of the data, it was descriptive research.

This research was conducted in the Plastic Sack Industry in Sidoarjo. The span of data collection was on 12 August 2019 to 20 September 2019. Observations in this study were carried out on 45 fire extinguishers spread in the Plastic Sack Industry

Table 1. The Classification of Fire at Plastic Sack Industry in 2019

\begin{tabular}{|c|c|c|}
\hline Location & Type of Material & Type \\
\hline \multirow{3}{*}{$\begin{array}{c}\text { Finished material } \\
\text { warehouse }\end{array}$} & Plastic sack & A \\
\hline & Ink & $\mathrm{B}$ \\
\hline & Thinner & $\mathrm{B}$ \\
\hline Jumbo bag & Plastic sack & A \\
\hline \multirow{2}{*}{ Adstar } & Plastic sack & A \\
\hline & Electricity & $\mathrm{C}$ \\
\hline \multirow{2}{*}{ Stacotex / Lamination } & Plastic sack & A \\
\hline & Electricity & $\mathrm{C}$ \\
\hline \multirow{4}{*}{$\mathrm{ABM}$} & Plastic sack & A \\
\hline & Ink & $\mathrm{B}$ \\
\hline & Thinner & $\mathrm{B}$ \\
\hline & Electricity & $\mathrm{C}$ \\
\hline \multirow{2}{*}{ Circular loom } & Plastic sack & A \\
\hline & Electricity & $\mathrm{C}$ \\
\hline \multirow{2}{*}{ Workshop } & Electricity & $\mathrm{C}$ \\
\hline & Fuel & $\mathrm{B}$ \\
\hline \multirow{2}{*}{ Test bag } & Plastic sack & A \\
\hline & Electricity & $\mathrm{C}$ \\
\hline \multirow{2}{*}{ Waste warehouse } & Ink & $\mathrm{B}$ \\
\hline & Thinner & $\mathrm{B}$ \\
\hline Extruder generator set & Electricity & $\mathrm{C}$ \\
\hline \multirow{2}{*}{ Extruder } & Plastic sack & A \\
\hline & Electricity & $\mathrm{C}$ \\
\hline Master generator & Electricity & $\mathrm{C}$ \\
\hline \multirow{2}{*}{ Kencana } & Plastic & A \\
\hline & Paper & $\mathrm{C}$ \\
\hline \multirow{2}{*}{ Kencana } & Fuel & $\mathrm{B}$ \\
\hline & Electricity & $\mathrm{C}$ \\
\hline Water pump & Electricity & $\mathrm{C}$ \\
\hline \multirow{2}{*}{ Office } & Paper and Plastics & $\mathrm{A}$ \\
\hline & Electricity & $\mathrm{C}$ \\
\hline
\end{tabular}


area. The research variable was the installation of fire extinguishers.

The data collection was carried out through field observation and measured using observation sheets and metlines to determine the dimensions of fire extinguisher installation. The data obtained was analyzed descriptively by illustrating the situation systematically and factually. Then, the data was presented in the form of narratives, tabulations, and images, so there would be clear pictures of fire extinguisher installation in the Plastic Sack Industry.

\section{RESULT}

\section{Hazard Identification}

Plastic Sack Industry is a manufacturing industry that produces plastic sacks with the main basic material is the polypropylene plastic pellets. The company's production is in the form of two sizes of plastic sacks, namely woven bags with a capacity of $25-50 \mathrm{~kg}$ and jumbo bags with a capacity of $500 \mathrm{~kg}$. This plastic sack industry has a workforce of \pm 1500 people and is divided into 3 work shifts. The marketing of plastic sack products has reached international level and has 3 industrial branches in Sidoarjo, Mojosari, and Nganjuk.

The results of observations at the Plastic Sack Industry show that several things can cause fires. Following the fire triangle theory, the cause of the fire can come from air or oxygen, heat, and combustible materials.

The source of the air comes from the oxygen in the environment of the Plastic Sack Industry. The heat source comes from machines used in the production process. Source of combustible material comes from solid materials, which is polypropylene plastic pellets and liquid materials in the form of color ink and thinner used as ink blends.

The level of classification of potential fire risk in the Plastic Sack Industry was included in the

Table 2. The Types, Colors, and Sizes of Fire Extinguishers at Plastic Sack Industry in 2019

\begin{tabular}{cccc}
\hline Type & Color & Capacity & Amount \\
\hline DCP & Red & $6 \mathrm{~kg}$ & 14 pieces \\
Pasca Halon & Yellow & $5 \mathrm{~kg}$ & 22 pieces \\
Foam & Blue & $9 \mathrm{~kg}$ & 9 pieces \\
\hline
\end{tabular}

moderate level of potential danger 3 . An industry is considered to have potential fire risk on level 3 because the workplace has a high number risk of fires. In addition, when a fire happens, it releases high heat, so the fire is spread quickly. In addition to the high potential for fire hazard, the Plastic Sack Industry has not yet had procedures related to the installation and maintenance of fire extinguisher and there was no team for fire prevention.

\section{Fire Extinguisher Installation}

Based on the results of observations conducted, it can be seen that the fire extinguisher that was available in the Plastic Sack Industry was 45 units spread in each production area and office.
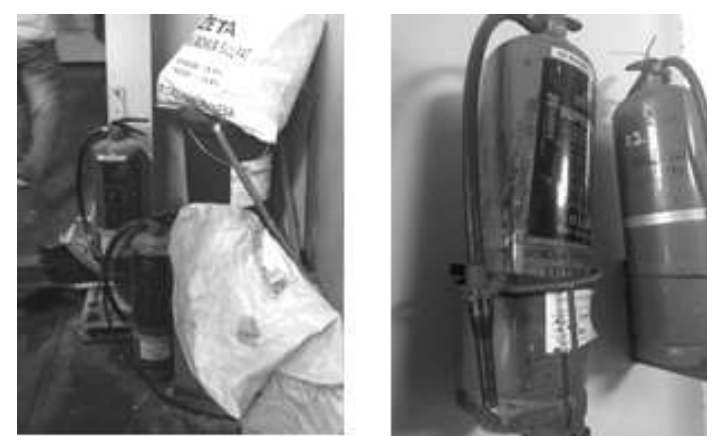

Figure 1. Condition of Fire Extinguisher at Plastic Sack Industry in 2019

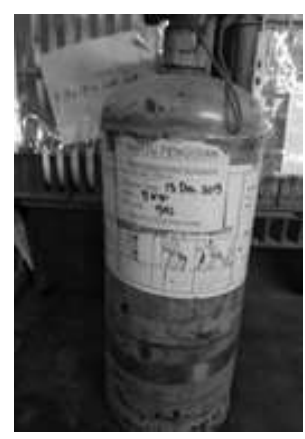

Figure 2. The Condition of Fire Extinguisher Label at Plastic Sack Industry in 2019

Table 3. Fire Extinguisher Installation Height at Plastic Sack Industry in 2019

\begin{tabular}{ccc}
\hline $\begin{array}{c}\text { Fire } \\
\text { Type }\end{array}$ & Appropriate & Inappropriate \\
\hline DCP & 7 pieces & 7 pieces \\
Pasca Halon & - & 22 pieces \\
Foam & - & 9 pieces \\
\hline
\end{tabular}




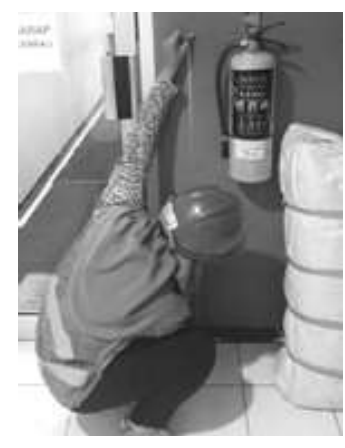

Figure 3. The Height Measurement of Fire Extinguisher at Plastic Sack Industry in 2019

\section{Type, Color, fire extinguisher Capacity}

The table 2 shows the types of the fire extinguishers in the Plastic Sack Industry included 14 units of Dry Chemical Powder (DCP), 22 units of Pasca Halon, and 9 units of Foam. The colors of fire extinguisher spread throughout the Plastic Sack Industry area based on the existing fire extinguisher types, namely red for Dry Chemical Powder (DCP) type, yellow for Pasca Halon type and blue for Foam type. The existing fire extinguisher capacity also varied between $5-9 \mathrm{~kg}$ depending on the type of fire extinguisher.

\section{Fire extinguisher condition}

The condition of fire extinguishers determines the quality of existing fire extinguisher. Based on the observations, there were 6 fire extinguishers placed on the floor, 7 fire extinguishers were fixed at locations that were difficult to reach and not easily seen. As many as 36 fire extinguishers experienced corrosive and the color of the fire extinguishers' tube is peeling off.

\section{Fire Extinguisher label}

The observation results indicated that there was a label that contains the required information such as fire extinguisher expiration date, type of fire extinguisher, fire extinguisher class, size or capacity of fire extinguisher and the operation procedures on the label. However, there were 36 corrosive fire extinguisher tubes so that the labels were damaged and could not even be read and covered by fire extinguisher filling stickers.

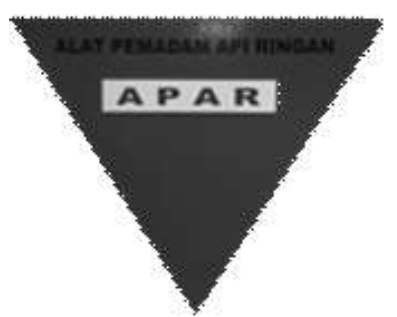

Figure 4. Fire Extinguisher Installation Mark at Plastic Sack Industry in 2019

\section{Fire Extinguisher Installation Height}

Measurement of fire extinguisher installation height was done by measuring it from the floor where the fire extinguisher was installed up to the very top or fire extinguisher handle.

The table 3 shows the height of fire extinguisher installed that was less than $120 \mathrm{~cm}$ and more than $120 \mathrm{~cm}$ as many as 38 units which were the type of Dry Chemical Powder (DCP), pasca Halon and Foam, as well as 7 units of fire extinguisher that were already in required position, namely with a height of $\leq 120 \mathrm{~cm}$ that was dry powder type fire extinguisher because the height was not more than $120 \mathrm{~cm}$ and the distance between the base fire extinguisher was not less than $15 \mathrm{~cm}$ from the surface of the floor.

\section{Fire Extinguisher Installation Mark}

The results from the observations showed that there were 29 APARs that were not marked with APAR installation and the 16 APARs that were marked with APAR installation were at the height of $<125 \mathrm{~cm}$ and $>125 \mathrm{~cm}$ from the floor. There were 16 fire extinguishers that have a mark of installation. However, the size of the fire extinguishers mark was $>35 \mathrm{~cm}$ and there was no arrow as a sign of fire extinguisher's existences in the dimension of triangle as required.

\section{The Distance of Each Fire Extinguisher}

The placement of fire extinguisher with one another was done on the recommendation of the Occupational Health and Safety (OHS) expert in the company and in each division in the Plastic Sack Industry, fire extinguisher has been installed. Base on the observation, fire extinguishers in the area of material warehouse, finished material warehouse, 
test bag, and main generator set were lined up with a distance of $10 \mathrm{~cm}$. While at other areas, the distance between fire extinguishers is \pm 5 -15 meters.

\section{DISCUSSION}

\section{Fire Identification}

In general, there were 3 types of resources available in the Plastic Sack Industry that can cause fires, those were the presence of flammable materials used during solid production process such as plastic and paper, and liquid materials such as ink and thinner. There was fuel found at the workshop location and vehicle repair shop but the amount was very small. Besides the flammable materials, there was oxygen that was spread throughout the industrial area that can react with the heat generated from electrical energy. In accordance with the statement of Ramli (2010), a fire occurred because of a meeting of the 3 factors that constitute the fire element. Those three factors include fuel, heat source, and oxygen (O2). Fuel elements are either solid, liquid or gas which can ignite and mix with oxygen from the air. The heat triggers a fire with enough energy to ignite a mixture of fuel and oxygen from the air.

Flammable materials used during production process in plastic sack industry such as ink and tinner can cause fire incident. Zhang (2018) in his research said that many explosions and fire incident can occur if chemical management is improper. Based on a survey conducted by Kironji (2015), it was found that as much as $78.5 \%$ of the buildings had been equipped with adequate and suitable fire extinguishers and $21.43 \%$ were not. The main factor that causes a mismatch is the misplacement of fire extinguishers which unfit with the classification of fire, lack of maintenance, and misuse of accessories that are in the fire extinguisher.

APAR is a mobile fire extinguisher as a form of first aid that is installed in the workplace for emergency needs (Kironji, 2015). Therefore, the suitability of fire extinguisher with the fire classification in a workplace is very important, because fire extinguisher is the first aid in case there is a fire.

The identification of potential fire hazards found in the Plastic Sack Industry were 3 types of fire classification, namely class A (fire due to solid materials such as paper, plastic, wood), class B (fire caused by liquid and gas fuels), and class $\mathrm{C}$ (fire at high voltage electricity). Whereas the fire extinguisher's types in the Plastic Sack Industry were Dry chemical powder, pasca-halon, and foam. Thus, if fire occurs, the fire extinguisher is available and can be used. The suitability between the fire classification classes in the Plastic Sack Industry and the types of fire extinguishers available can be considered to have fulfilled the requirements of the Indonesian Ministry of Manpower and Transmigration PER. 04/MEN/1980 regarding the Requirements for the Installation and Maintenance of Light Fire Extinguishers.

Plastic sack industry is an industry with a medium level of risk of fire level 3 , due to the absence of procedures related to the installation and maintenance of fire extinguisher and the fire prevention team that can endanger the workforce. According to Lestaluhu (2019), the thing that affects the success of early fire prevention is the correct use of fire extinguisher, thus training in the form of theory and practice is very necessary because with the training, workers can understand how to use fire extinguisher properly. Therefore, the absence of fire extinguisher installation and maintenance procedures can affect the fire prevention process in the workplace due to the ignorance of workers regarding how to deal with fire and the proper use of fire extinguisher.

\section{Fire Extinguisher Installation}

\section{Type, Color, Fire Extinguisher Capacity}

The types of the fire extinguishers in the Plastic Sack Industry included 14 units of Dry Chemical Powder (DCP), 22 units of Pasca Halon, and 9 units of Foam. Fire classification that may occur in the Plastic Sack Industry is fire classes A, B, and C. This is due to the presence of flammable solid materials, which are plastic polypropylene seeds and paper, flammable liquid materials, namely ink and thinner, and the presence of electrical energy as a heat producer for production equipment. Appropriate fire extinguishers for the three fire classes are pasca Halon and dry chemical powder (DCP), while fire extinguisher with foam types are suitable for fire classes A and B. Based on this, the selection of fire extinguisher types in the Plastic Sack Industry area is in accordance with the Indonesian Ministry of Manpower and Transmigration PER. 04/MEN/1980 concerning the requirements for Fire Extinguisher Installation and Maintenance of article 4 paragraph 4 , that the installation and placement of fire 
extinguisher is in accordance with the type and classification of fire.

According to Lestaluhu (2019), Dry Chemical Powder fire extinguisher is an effective and versatile type of fire extinguisher to fight Class A, B and $\mathrm{C}$ fires, and is suitable for dealing with high risk situation. Besides being useful in overcoming electrical hazards, flammable liquids and gases, Dry Chemical Powder is also effective for fire that occurs in vehicles.

According to Wahyudi (2005), the use of Dry Chemical Powder to overcome fire is very difficult to clean, since hot Dry Chemical Powder will become sticky like glue. The use of DCP is less effective and the right type of fire extinguisher is Pasca Halon because it is clean, does not damage equipment and machine, does not leave residues and is nonconductive. Therefore, Pasca Halon type fire extinguisher was found in the Plastic Sack Industry both in production and in the office because it does not cause damage.

Fire extinguisher's colors in the Plastic Sack Industry consisted of 3 colors, those are red, yellow and blue. According the Indonesian Ministry of Manpower and Transmigration PER. 04/MEN/1980 regarding the requirements of Fire Extinguisher Installation and Maintenance of article 4 paragraph 6 , it is stated that each tube of a fire extinguisher should be red. Based on this, it can be considered that the color of fire extinguisher in the Plastic Sack Industry was not in accordance with the regulations because there were still yellow and blue tubes.

\section{Fire Extinguisher's Condition}

The placement of 7 fire extinguishers in the production area of the Plastic Sack Industry was mostly in a position that is not easily seen because fire extinguisher was placed behind a pile of semifinished raw materials, finished goods and behind the machine. The fire extinguisher was also placed in an area that was rarely passed by workers and had poor access to go to the proper location of fire extinguisher placement because of the collision of goods and machinery. In addition, there were still 6 fire extinguishers that were deliberately placed on the floor because there were no hooks as a buffer. Based on this, the placement of the fire extinguisher in the Plastic Sack Industry was not in accordance with the Indonesian Ministry of Manpower and Transmigration PER. 04/MEN/1980 regarding the requirements for Fire Extinguisher Installation and Maintenance which states that each one group of light fire extinguishers must be placed on a position that is easily seen clearly, easily reached and taken and is equipped with a sign of installation.

Sanjaya and Maria (2015) stated that compliance with standards cannot be ruled out, considering that if a fire does occur and there are still components that do not meet the standards, it will result in large loss and even fatalities. The same thing was said by Firdani, Ekawati and Kurniawan (2014) that the condition of fire extinguisher is very crucial on the feasibility of the fire extinguisher itself, both when and will be used because if a fire extinguisher is in a good condition, then the risk of a greater fire can be overcome immediately.

In addition to the placement of the fire extinguisher which is not easily seen and reached, there were 36 fire extinguishers in the Plastic Sack Industry whose tube experiencing corrosive and color was exfoliated. According to the National Fire Protection Association (2013), if a fire extinguisher is in an expired and rusted condition, it is prohibited to be used and can possibly cause danger. The same thing was said by Hambyah (2016) that a fire extinguisher that has expired or rusty, does not have a performance that matches the original specifications. The material contained in fire extinguisher may not work as it supposed to do, thus it is not effective in putting out the fire. In addition, there is usually also a decrease in pressure which causes fire extinguisher to not reach the hotspots optimally. Djunaidi, Tuah and Rafifah (2018) on their research said that if active and passive fire protection systems in office buildings are not adequately practiced in accordance with standards and regulations, it can result in heavy loss to the organization in terms of injury to the workforce, financial loss due to property and equipment damage and legal consequences.

\section{Fire Extinguisher's Label}

The label on the fire extinguisher tube consisted of the type of the fire extinguisher, level of fire extinguished, capacity, method of use, and expiration date of the fire extinguisher. Plastic sack industry had 36 corrosive fire extinguisher tubes so that the labels were damaged and could not even be read and covered by fire extinguisher filling stickers. The results of the research conducted by Yeturu et al., (2016) stated that among as many as 270 people that participated in the study, almost half of the participants had a positive attitude towards fire safety and very few participants knew the steps to 
control it in the event of a fires. Based on this, one way to control fires is to extinguish the small fire by using a fire extinguisher. Therefore, the label of the fire extinguisher in the form of method of the use must be available and can be read clearly in anticipation if in an emergency, someone who will use a fire extinguisher does not know how to use it.

Moreover, research conducted at Grasia Hotel showed that fire extinguisher was not equipped with fire extinguisher operation instructions and fire extinguisher usage instructions should be attached in the front position so that they could be read clearly. These instructions for fire extinguisher operation instructions are useful for someone who will use fire extinguisher but does not know how to use them, and therefore each fire extinguisher should have instructions for fire extinguisher operation (Miranti and Mardiana, 2018).

\section{Height of Fire Extinguisher Installation}

There were inconsistency found in the height of fire extinguisher installation in the Plastic Sacks industry where there were 38 fire extinguishers installed on more than $120 \mathrm{~cm}$ from the floor whereas the other 6 of 38 fire extinguishers were still placed on the floor. Inconsistency found in height of fire extinguisher which were the type of Dry Chemical Powder (DCP), pasca Halon and foam. This is not in accordance with the Indonesian Ministry of Manpower and Transmigration PER. 04/MEN/1980 concerning the requirements for fire extinguisher Installation and Maintenance article 6 (1) which reads that every light fire extinguisher must be installed (placed) hanging on the wall by reinforcement or by reinforcing construction other or placed in a cabinet or box that is not locked, and article 8 which reads fire extinguisher installation must be such that the topmost part is at a height of 1.2 meters from the floor surface except the type of $\mathrm{CO} 2$ and dry chemical can be placed more low on condition, the distance between the fire extinguisher base is not less than $15 \mathrm{~cm}$ from the floor surface.

Moreover, the research conducted by Hambyah (2016) in the Surgical Units of RSUD Dr. Soetomo in Surabaya showed the result that is the fire extinguisher in the Surgical Hospital Dr. Soetomo on average was at an altitude of $1.5 \mathrm{~m}-1.6 \mathrm{~m}$, some were even at an altitude of $1.8 \mathrm{~m}$. According to him, the installation of fire extinguisher exceeded the recommended standard, it was feared that fire extinguisher would be difficult to reach during an emergency, because the installation was too high.

\section{Fire Extinguisher Installation Mark}

The Plastic Sack Industry had 16 fire extinguishers which were equipped with the mark for fire extinguisher installation and had a height of $<125 \mathrm{~cm}$ and $>125 \mathrm{~cm}$ from the floor surface. This is not in accordance with the regulations from the Indonesian Ministry of Manpower and Transmigration PER. 04/MEN/1980 regarding the requirements for Installation and Maintenance of article 4 paragraph 3 , in which the height of the marking of fire extinguisher installation is $125 \mathrm{~cm}$ from the floor surface or above one of the groups of light fire extinguishers concerned. There were still many fire extinguishers in the Plastic Sack Industry that were placed without installation signs. According to Romadhon (2018), damage or absence of a sign of extinguisher installation results in increased search time by workers in the event of an immunity. Firdani, Ekawati and Kurniawan (2014) also said that extinguisher place marks are very important for fire prevention purposes; with the existence of extinguisher place marks, workers will be easier to know the location of extinguisher.

The results of research conducted by Kowara and Martiana (2017), stated that the suitability level of the active fire protection system, namely fire extinguishers in the office building of PT PJB UP Brantas Malang in 2016, amounted to $72 \%$ are in accordance with the requirements in the Indonesian Ministry of Manpower and Transmigration PER. 04/MEN/1980 regarding the requirements for fire extinguishers Installation and Maintenance. The elements of the fire extinguishers that were still lacking were due to not functioning optimally, including not finding the proper and correct fire extinguishers installation signs so that it was difficult to find the location of the fire extinguisher when fire occurred.

Fire extinguishers in the Plastic Sack Industry had a sign of fire extinguisher installation. However, the size of the fire extinguisher mark in the Plastic Sack Industry was $>35 \mathrm{~cm}$ and there were no arrows. This is not in accordance with the Indonesian Ministry of Manpower and Transmigration PER. 04/MEN/1980 regarding the requirements for Installation and Maintenance of article 4 (2) that the marking of the installation must be appropriate, namely the marking of fire extinguisher on an equilateral triangle with a red base color, with the side size is $35 \mathrm{~cm}$, height of the 
letter "Fire Extinguisher" is $3 \mathrm{~cm}$ in the red color and the height of the arrow is $7.5 \mathrm{~cm}$ in white.

Moreover, based on research conducted by Castel, Vendetti and Holyoak (2012) on 'Fire drill: unintentional blindness and amnesia for the location of fire extinguisher, it was known that $60 \%$ of the 54 people studied did not know the location of the fire extinguishers in work place. According to him, although people did not remember where the location of the fire extinguisher was, they could find with a red mark as a pointer to the fire extinguisher so they can find it. However, it is different if there is a fire due to environmental conditions such as smoke and psychological conditions such as anxiety, confusion and stress that can be potentially dangerous because the sign of the installation of a fire extinguisher may be invisible, therefore it must rely on memory to find a fire extinguisher.

\section{Distance between the Fire Extinguishers}

The placement of Fire Extinguisher in the Plastic Sack Industry area was carried out based on the recommendation of the Occupational Health and Safety (OHS) expert in the company. The results of a study conducted by Firdani, Ekawati and Kurniawan (2014) in the Textile Industry of PT X Pekalongan showed that there were 26 fire extinguishers that did not comply with the regulations; this was because the distance between the fire extinguishers exceeded 15 meters. As many as 4 respondents of the survey stated that the distance between fire extinguishers which were more than 15 meters can be difficult for workers if a fire breaks out.

According to the Indonesian Ministry of Manpower and Transmigration PER. 04/MEN/1980 concerning the requirements for fire extinguisher Installation and Maintenance article 4 (5) stating that the placement of fire extinguisher from one to another fire extinguisher does not exceed 15 meters unless determined by the Occupational Health and Safety (OHS) expert himself. So that the placement of fire extinguisher one with another in the Plastic Sack Industry can be said to be in accordance with existing provisions because the distance is determined by the Occupational Health and Safety (OHS) expert.

\section{CONCLUSION}

Fire extinguisher installation in Plastic Sack Industry have not fulfilled the requirements as listed in the Indonesian Ministry of Manpower and
Transmigration PER. 04/MEN/1980, such as: the lack of fire extinguisher installation, maintenance procedures and fire prevention teams; color of fire extinguisher; height of fire extinguisher installation in which out of 45 fire extinguishers, only 7 fire extinguishers complies with the regulations; the fire extinguisher condition, in which many of the fire extinguishers were rusty and have peeled color and the placement of the fire extinguisher is placed in an area that is not easily seen and reached; the label on the fire extinguisher tube is mostly covered with the stickers from fire extinguisher fillings and corrosive so that the label is damaged; and there are 29 fire extinguishers that are not equipped with the marker of fire extinguisher installment whereas 16 fire extinguishers that already have the markers were still not in accordance to the requirements.

\section{ACKNOWLEDGEMENTS}

The author expresses his gratitude to Ms. Wahyu Widiyati as a field supervisor in the Plastic Sack Industry for providing advice, assistance and support to complete this research and the workers who cannot be mentioned one by one who have helped me in finishing this research.

\section{REFERENCES}

Castel, A. D., Vendetti, M. and Holyoak, K. J. (2012) 'Fire drill : Inattentional blindness and amnesia for the location of fire extinguishers', 74, pp. 1391-1396

Djunaidi, Z., Tuah, N. and Rafifah, G. (2018) 'Analysis of the Active and Passive Fire Protection System in the Government Building, Depok City, Indonesia', KnE Life Science 4(5), pp. 384-398.

Firdani, L., Ekawati, - and Kurniawan, B. (2014) 'Analisis Penerapan Alat Pemadam Api Ringan (APAR) Di PT. X Pekalongan', Jurnal Kesehatan Masyarakat (e-Journal), 2(5), pp. 300-308.

Hambyah, R. F. (2016) 'Evaluasi Pemasangan APAR Dalam Sistem Tanggap Darurat Kebakaran Di Gedung Dr. Soetomo Surabaya', The Indonesian Journal of Occupational Safety and Health, 5(1), pp. 41-50.

Menteri Tenaga Kerja Republik Indonesia (1999) Keputusan Menteri Tenaga Kerja Republik Indonesia KEP.186/MEN/1999 Tentang Unit Penanggulangan Kebakaran Di Tempat 
Kerja. Jakarta: Menteri Tenaga Kerja Republik Indonesia.

Kironji, Maina (2015) Evaluation of Fire Protection Systems in Commercial Highrise Buildings for Fire Safety Optimization 'A Case of Nairobi Central Business District'. International Journal of Scientific and Research Publication, 5(10), pp. 1-8

Kowara, R.A. and Martiana, T (2017) Analysis of Fire Protection Systems as Fire Prevention and Mitigation Efforts (Study at PT. PJB UP Brantas Malang). Jurnal Manajemen Kesehatan Yayasan RS Dr. Soetomo, 3(1), pp.70-85

Lestaluhu, F (2019) Installation and Maintenance of Portable Fire Extinguishers at PT E-T-A Indonesia Sidoarjo. The Indonesian Journal of Occupational Safety and Health, 8(1), pp. 38-46.

Menteri Tenaga Kerja Dan Transmigrasi Indonesia (1980) Menteri Tenaga Kerja Dan Transmigrasi Indonesia PER.04/MEN/1980 Tentang Syaratsyarat Pemasangan dan Pemeliharaan Alat Pemadam Api Ringan. Jakarta: Menteri Tenaga Kerja Dan Transmigrasi Indonesia.

Miranti, R. S. and Mardiana (2018) 'Penerapan Sistem Proteksi Aktif dan Sarana Penyelamatan Jiwa Sebagai Upaya Pencegahan Kebakaran', Higea Journal Of Public Health Reasearch And Development, 2(1), pp. 12-22.

National Fire Protection Association (2013) NFPA 10, Standard Portable Fire Extinguishers 2013 Edition. United States of America: National Fire Protection Association.
Pemerintah Republik Indonesia (1970) UndangUndang No. 1 Tahun 1970 Tentang Keselamatan Kerja.

Ramli, S. (2010) Management Kebakaran. Surabaya : Dian Rakyat

Romadhon, B. (2018) 'Fire Protection Analysis On Gas Production Company And Power Plant', The Indonesian Journal of Occupational Safety and Health, 7, pp. 142-151.

Sanjaya, M and Maria, U. (2015) Evaluation Of Hospital Facilities And Infrastructure In Dealing With Fire Disaster (Case Study in PKU Muhammadiyah Yogyakarta Unit II Hospital). Jurnal Medocoeticoilegal dan Manajemen Rumah Sakit, 4(2), pp. 1-20

Suma'mur, P. K. (2009) 'Higiene Perusahaan dan Kesehatan Kerja (Hiperkes)', Jakarta: Sagung Seto.

Tarwaka (2012) Basic Safety Work and Prevention of Accidents at Work. Surakarta: Harapan Press.

Wahyudi, S. (2005) Studi Tentang Pencegahan Kebakaran dan Alat Pemadam Api Ringan, Gresik : Departemen Keselamatan PT Petrokimia Gresik.

Yeturu, S. K. et al. (2016) 'Assessment of Knowledge and Attitudes of Fire Safety - An Institution Based Study', Journal of Pharmaceutical Science and Research, 8(11), pp. 1281-1284.

Zhang, C. (2018) 'Analysis Of Fire Safety System Fot Storage Enterprises Of Dangerous Chemichals', Procedia Engineering, 211, pp. 986-995. 